University of Windsor

Scholarship at UWindsor

1993

\title{
PCR primed with VNTR core sequences yields species specific patterns and hypervariable probes
}

Daniel D. Heath

University of Windsor

George K. Lwama

Robert H. Devlin

Follow this and additional works at: https://scholar.uwindsor.ca/biologypub

Part of the Biology Commons

\section{Recommended Citation}

Heath, Daniel D.; Lwama, George K.; and Devlin, Robert H., "PCR primed with VNTR core sequences yields species specific patterns and hypervariable probes" (1993). Nucleic Acids Research, 21, 24, 5782-5785. https://scholar.uwindsor.ca/biologypub/1106

This Article is brought to you for free and open access by the Department of Biological Sciences at Scholarship at UWindsor. It has been accepted for inclusion in Biological Sciences Publications by an authorized administrator of Scholarship at UWindsor. For more information, please contact scholarship@uwindsor.ca. 


\title{
PCR primed with VNTR core sequences yields species specific patterns and hypervariable probes
}

\author{
Daniel D.Heath ${ }^{+}$, George K.Iwama ${ }^{1}$ and Robert H.Devlin* \\ Fisheries and Oceans Canada, West Vancouver Laboratory, 4160 Marine Drive, West Vancouver, \\ BC V7V 1N6 and 'Department of Animal Science, and Canadian Bacterial Disease Network, \\ University of British Columbia, 2357 Main Mall, Suite 248, Vancouver, BC V6T 1Z4, Canada
}

\begin{abstract}
The use of genomic DNA-based techniques in ecological and evolutionary studies has been limited by the availability of suitable probes for species of interest due to the technical difficulty of isolating and applying such probes. We have developed a simple technique that directs polymerase chain reaction (PCR) amplification to regions rich in variable number of tandem repeats (VNTRs). By using published VNTR core sequences as primers in PCRs, fragments were amplified that showed little variation within a species, but did show differences between species. When the amplified fragments were used as probes with genomic DNA Southern blots they produced hypervariable singlelocus or few-locus patterns in fish, birds, and humans. We have named this procedure as Directed Amplification of Minisatellite-region DNA (DAMD).
\end{abstract}

\section{INTRODUCTION}

In general, PCR techniques have many potential applications in ecological and evolutionary studies due to their technical ease and the small amount of DNA required (1). PCR techniques such as random amplification of polymorphic DNA (RAPD) $(2,3)$ have been used for the analysis of parentage and kinship $(1,4,5)$, for stock and strain identification (1), and for species identification $(1,4,6)$ in wild and experimental populations of plants and animals. One drawback of RAPD is the low stringency necessary for successful amplification which can lead to non-reproducible banding patterns (7). Since minisatellite or VNTR sequences occur in many diverse species of plants and animals (8) they should be effective as PCR primers at relatively high stringencies in a wide range of species. Furthermore, we reasoned that at some VNTR loci, some of the repeated core sequences may become inverted in orientation due to local inversions or other chromosomal rearrangements. If such events moved repeats so that single-copy DNA was present between them, then PCR using a single VNTR core primer may amplify sequences historically adjacent to highly variable loci. This PCR application, Directed Amplification of Minisatellite-region DNA (DAMD), would thus produce RAPD-like results at considerably higher reaction stringencies and the amplified fragments could also potentially be used as single-locus VNTR probes without the necessity of DNA library screening, cloning or sequencing. We have used DAMD to produce species-specific electrophoretic banding patterns for three species of salmonids, humans and birds. A single-locus VNTR DNA probe was subsequently developed from chinook salmon (Oncorhynchus tshawytscha) DNA, and two other potentially useful probes from quail (Coturnix japonica) and human DNA.

\section{MATERIALS AND METHODS}

Polymerase chain reaction

Genomic DNA was extracted from blood or tissue using a modified salt-precipitation protocol described elsewhere (9). Approximately $200 \mathrm{ng}$ of genomic DNA from chinook salmon, human, and quail were used as template for $50 \mu \mathrm{l}$ PCRs. Each reaction had $500 \mathrm{ng}$ of one of the synthetic oligonucleotides INS, YNZ22, M13, YN73, and PER1 as primer (VNTR core sequences: INS, ACAGGGGTGTGGGG (10); YNZ22, CTCTGGGTGTCGTGC (10); M13, GAGGGTGGNGGNTCT (11); YN73, CCCGTGGGGCCGCCG (12); PER1, GACNGGNACNGG (13)); smaller amounts of primer yielded unreliable results. The balance of the PCR was Cetus buffer $(50 \mathrm{mM} \mathrm{KCl}$, $10 \mathrm{mM}$ Tris $(\mathrm{pH}=8.3), 100 \mu \mathrm{g} / \mathrm{ml}$ gelatin $), \mathrm{MgCl}_{2}(1.5 \mathrm{mM})$, dNTPs $(200 \mu \mathrm{M}$ each), and Taq DNA polymerase $(0.05 \mathrm{U} / \mu \mathrm{l})$. Reactions were run for 35 cycles with a $55^{\circ} \mathrm{C}$ annealing cycle $(1.0 \mathrm{~min}), 72^{\circ} \mathrm{C}$ extension cycle $(1.5 \mathrm{~min})$, and a $95^{\circ} \mathrm{C}$ denaturing cycle $(1.0 \mathrm{~min})$ in a Perkin Elmer Cetus DNA thermal cycler. The resulting reactions were fractionated on $1.5 \%$ low melting point agarose gels for $3-4 \mathrm{hr}$ at $70 \mathrm{~V}$ in a coldroom $\left(-8^{\circ} \mathrm{C}\right)$. Under UV transillumination, clearly distinguishable bands were cut out and stored at $-20^{\circ} \mathrm{C}$.

\section{Fragment hybridization}

Genomic DNA from each of the three species were digested with Hae III, size fractionated on $0.5 \%$ agarose gels, and transferred to Nylon membranes as described elsewhere (14). Individual

\footnotetext{
* To whom correspondence should be addressed

+ Present address: Department of Biological Sciences, University of South Carolina, Columbia, SC 29208, USA
} 
DAMD-generated DNA fragments from chinook salmon, human, and quail were screened for potential single-locus probes by hybridization with the Southern blots of genomic DNA from their respective species. The frozen gel slices were heated to $68^{\circ} \mathrm{C}$ for $15-30 \mathrm{~min}$, then $8.0 \mu \mathrm{l}$ were immediately added to a $50 \mu \mathrm{l}$ random priming reaction as described elsewhere (15). The random priming reactions were incubated at $37^{\circ} \mathrm{C}$ to minimize the solidification of the agarose. The membranes were hybridized with the radiolabelled DNA fragments (16), washed, and exposed to X-ray film for $1-2$ days with an intensifying screen at $-70^{\circ} \mathrm{C}$. A total of 26 gel slices (i.e. bands resulting from the DAMD) were screened: 12 chinook salmon, 8 human, and 6 quail gel slices. a

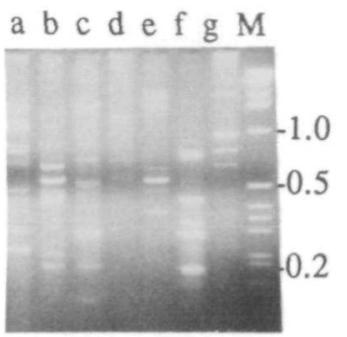

b

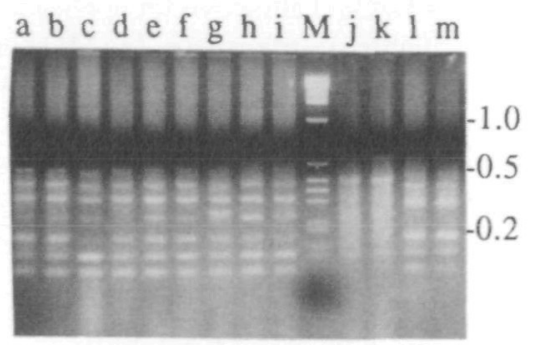

Figure 1. Results of PCR using a known VNTR core sequence as primer, $1 \mathrm{~Kb}$ ladder marker lanes (M) are identified on each gel. Gel a: Lane a is chinook salmon DNA as template with YN73 oligonucleotide as primer. Lanes $b-d$ are human DNA as template with YN73, M13, and PER1 respectively as primers. Lanes $\mathrm{e}-\mathrm{g}$ are quail DNA as template and INS, YN73, and YNZ22 as primers. Gel b: Lanes $a-i$ are chinook salmon DNA from nine unrelated individuals as template with M13 as primer (unrelated individuals were randomly selected salmon from a large mating population). After the marker lane the next two lanes (lanes $\mathrm{j}$ and $\mathrm{k}$ ) are Atlantic salmon (Salmo salar) DNA from two unrelated individuals as template with $\mathrm{M13}$ as primer. The last two lanes (lanes 1 and $\mathrm{m}$ ) are rainbow trout (Oncorhynchus mykiss) DNA from two unrelated individuals as template with $\mathrm{M} 13$ as primer.

\section{Sequencing}

One chinook salmon DNA fragment ( $\sim 400$ base pairs) that appeared to detect a highly-variable locus was re-amplified using 'touchdown' PCR protocol (17). The thermal cycles started at an annealing temperature of $65^{\circ} \mathrm{C}$ and reduced by one degree each subsequent cycle to a minimum of $50^{\circ} \mathrm{C}$, followed by an additional 20 cycles at $50^{\circ} \mathrm{C}$ annealing temperature. The PCR product was gel purified following the protocol of Prep-A-Gene DNA Purification Matrix (Bio-Rad, Life Science Group, Hercules, CA, USA). The PCR-amplified DNA was blunt-ended with T4 DNA polymerase (14) and cloned into the pBluescript II SK + vector (Stratagene Cloning Systems, LaJolla, CA, USA) (14). Double- and single-stranded DNA were prepared from the positively screened clone and sequencing was performed in both orientations using a Sequenase kit (United States Biochemical Corp.) and was analyzed with PCGene software (Intelligenetics).

\section{RESULTS AND DISCUSSION}

DAMD yielded fragment patterns with from one to ten clearly distinguishable bands using chinook salmon, human, and quail DNA templates. The number and positions of those bands depended on species and primer (Fig. 1). Although there was some variation between individual chinook salmon with a single primer (Fig. 1b), most of the bands were not variable. There were, however, significant and consistent differences between the three species of salmonids, with the more closely related rainbow trout, Oncorhynchus mykiss, and chinook salmon having more bands in common than with the Atlantic salmon, Salmo salar (Fig. 1b). Even greater differences were evident between fish, birds and humans (Fig. 1a). Consistent differences in banding patterns have also been observed between striped bass (Morone saxatilis), white bass (Morone chrysops), and white flounder (Pseudopleuronectes americanus) using DAMD (B. Ely, pers. commun.; Dept. of Biological Sciences, University of South Carolina, Columbia, SC).
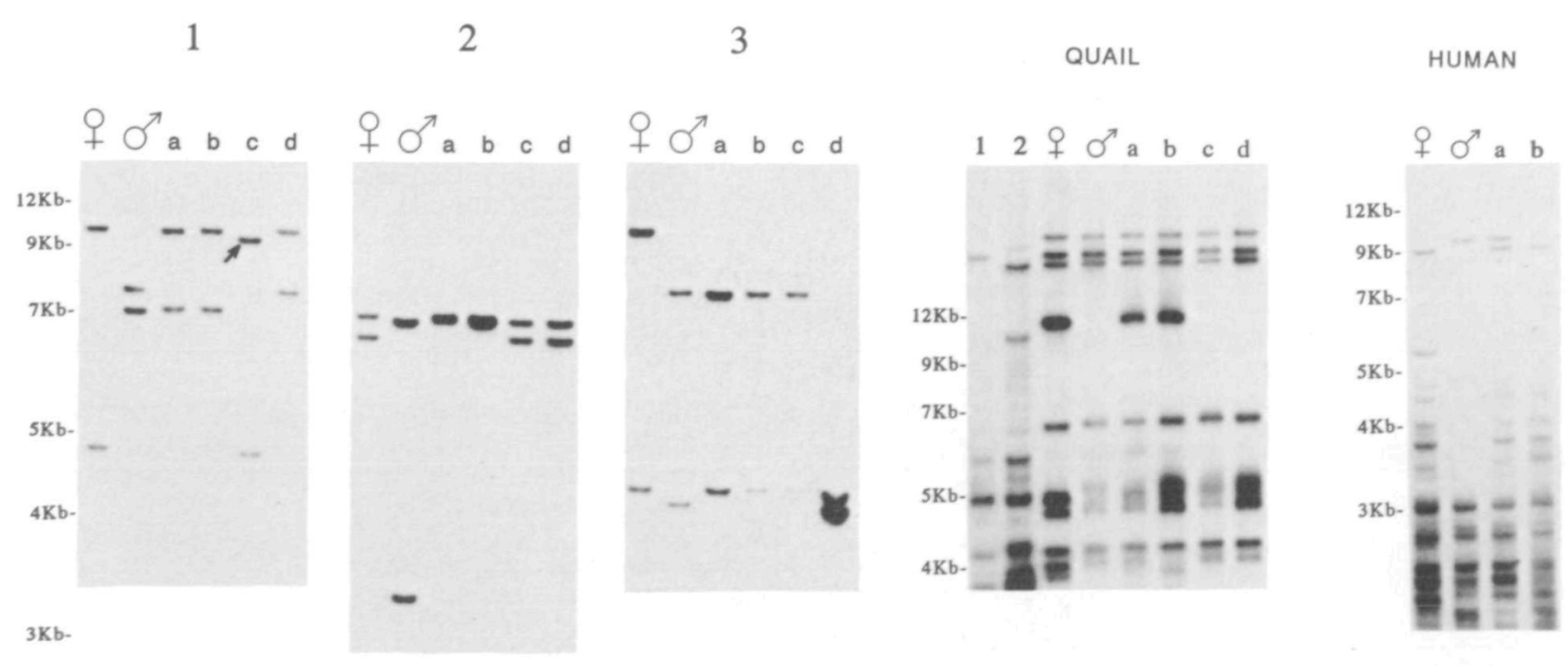

Figure 2. Autoradiographs of membranes probed with radiolabelled DNA fragments generated by random hexamer priming (15) of DAMD-derived potential singlelocus probes. Autoradiographs 1-3 show families of chinook salmon hybridized with the chinook salmon probe OtSL1. All alleles segregated faithfully from parents to offspring, except for the paternal allele in offspring ' $c$ ' in family 1 (marked by an arrow). This mutation represents an increase in molecular size of between 1 and $2 \mathrm{~kb}$, depending on which paternal allele mutated. The quail autoradiograph ('QUAIl') shows two unrelated individuals (lanes 1 and 2), and female and male parents with four offspring (lanes a-d). The human film ('HUMAN') shows female and male parents with two offspring (lanes a and b). 
When DAMD-generated fragments were hybridized with genomic DNA, they yielded one highly variable single-locus probe (named OtSL1) for chinook salmon from only twelve fragments screened. DAMD also generated one human probe and one quail probe that gave relatively simple banding patterns (Fig. 2) from eight and six fragments screened respectively.

Analysis of a natural chinook salmon population with the salmon probe OtSL1 revealed extensive variation (15 distinct alleles) and over $90 \%$ heterozygosity among twelve individuals examined (Fig. 3). The bands detected segregated faithfully to offspring in three families, except for one mutated allele in the first family shown in Fig. 2. To investigate the mutability of this locus further, 23 offspring from the same family were hybridized with the OtSL1 probe but no further mutant alleles were observed (data not shown). Analysis of the allele distribution in all offspring showed that the segregation was not significantly different from Mendelian inheritance ( $\chi^{2}$ test; $\left.P>0.10\right)$. The mutation rate observed at the OtSL1 locus (approximately $2 \%$, although based on only a single event) is consistent with estimates from other VNTR loci $(18-20)$.

The quail DAMD probe hybridized at two or three loci. It is difficult to determine the segregation of the bands in the quail since the parents were from inbred stock and showed very little variation (Fig. 2). However, two unrelated quail (lanes 1 and 2, Fig. 2) show that there is variation at these loci. The human probe yielded a $9 \mathrm{~kb}$ single-locus banding pattern that differed between parents, with a multi-locus pattern at lower molecular sizes (Fig. 2). Although only a single allele is identified in each parent, both alleles segregated to offspring. Homozygosity can be ruled out for the male parent since only one offspring obtained his allele. The second male parent band may be present at a lower molecular size and thus obscured by the multi-locus signal.

The nucleotide sequence of OtSL1 was 382 bases long and, as anticipated, the VNTR core sequence was present in opposite orientation at either end of the sequence (GenBank accession number U02549). The VNTR core sequence primers were found to be missing two bases each at $3^{\prime}$ and $5^{\prime}$ end of the fragment, presumably due to the exonuclease activity of the T4 DNA polymerase during the blunt-ending reaction. The OtSL1 fragment had two other short repeat sequences (distinct from the VNTR primer) present within it. The presence of three repeat

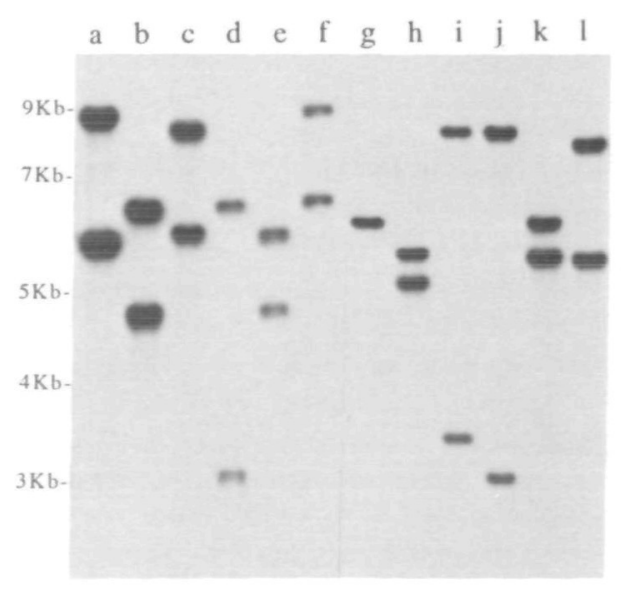

Figure 3. Southern blots of genomic DNA from twelve individual unrelated chinook salmon probed with the OtSL1 hypervariable probe. structures within this short sequence suggests that DAMDgenerated fragments are derived from regions rich in repeat sequences. Amplification of the OtSLl fragment occurred from oppositely oriented VNTR repeats, analogous to the PCR process that amplifies fragments between Alu repeats in human DNA (21).

Although we were unable to determine the exact organization of the OtSL1 locus (for example whether it contained a local inversion), the fragment did hybridize with chinook salmon genomic DNA at a single highly variable locus. Furthermore, the extreme variation in allele size detected at the OtSL1 locus in chinook salmon is very likely due to VNTR variation, perhaps involving one of the three repeat sequences identified.

DAMD represents a potentially useful tool for the identification of species (and perhaps populations or stocks) of organisms using a PCR-based assay. The small amount of DNA required for PCR makes DAMD attractive for applications where only limited tissue is available. Furthermore, DAMD can also be used to efficiently generate highly variable single-locus probes for species where genomic libraries and other molecular tools have not yet been developed. Although many VNTR core sequences have been documented $(10,12)$, it is unlikely that DAMD, by itself, would be capable of generating the large number of markers needed for projects such as genetic linkage maps. The chinook salmon probe (OtSL1) was cloned and sequenced in this study, however, this generally would not be necessary for the application of DAMD-generated probes to biological problems associated with relatedness, kinship, or individual identification.

\section{ACKNOWLEDGEMENTS}

This work was supported by an operating grant from Fisheries and Oceans Canada to RHD, NSERC and Canadian Bacterial Disease Network operating grants to GKI, and a Science Council of B.C. award to DDH. We would like to thank Dr K.Cheng (University of British Columbia) for providing quail blood and J.Theilman (University of British Columbia) for providing human DNA.

\section{REFERENCES}

1. Hadrys,H., Balick,M. and Schierwater,B. (1992) Mol. Ecol., 1, 55-63.

2. Williams,J.G.K., Kubelik,A.R., Livak,K.J., Rafalski,J.A. and Tingey,S.V. (1990) Nucleic Acids Res., 18, 6531-6535.

3. Welsh,J. and McClelland,M. (1990) Nucleic Acids Res. 18, 7213-7218.

4. Arnold,M.L., Buckner,C.M. and Robinson,J.J. (1991) Proc. Nat. Acad. Sci. U.S.A., 88, 1398-1402.

5. Scott,M.P., Haymes, K.M. and Williams,S.M. (1992) Nucleic Acids Res., 20, 5493.

6. Chapco,W., Ashton,N.W., Martel,R.K.B. and Antonishyn,N. (1992) Genome, 35, 569-574.

7. Riedy,M.F., Hamilton III,W.J. and Aquadro,C.F. (1992) Nature 355, 679.

8. Ryskov,A.P., Jincharadze,A.G., Prosnyak,M.I., Ivanov,P.L. and Limborska,S.A. (1988) Federation of European Biochemical Societies Letters, 233, 388-392.

9. Devlin,R.H., McNeil,B.K., Groves,D.D. and Donalson,E.M. (1991) Can. J. Fish. Aquat. Sci., 48, 1606-1612.

10. Nakamura,Y., Leppert,M., O'Connell,P., Wolff,R., Holm, T., Culver,M., Martin,C., Fujimoto,E., Hoff,M., Kumlim,E. and White,R. (1987) Science, 235, 1616-1622.

11. Vassart,G., Georges,M., Brocas,H., Lequarre,A.S. and Cristophe,D. (1987) Science, 235, 683-684.

12. Nakamura,Y., Carlson,M., Krapcho,K., Kanamori,M. and White,R. (1988) Am. J. Hum. Genet., 43, 854-859.

13. Georges,M., Lequarre,A.S., Castelli,M., Hanset,R. and Vassart,G. (1988) Cytogenet. Cell. Genet., 47, 127-131. 
14. Sambrooke,J., Fritsch,E.F. and Maniatis,T. (1989) Molecular Cloning: A Laboratory Manual. Cold Spring Harbor Laboratory Press, Cold Spring Harbor.

15. Feinberg,A.P. and Vogelstein,B. (1984) Anatyt. Biochem., 137, 266-267.

16. Westneat,D.F., Noon,W.A., Reeve,H.K. and Aquadro,C.F. (1988) Nucleic Acids Res., 16, 4161.

17. Don,R.H. Cox,P.T., Wainwright,B.J., Baker,K. and Mattick,J.S. (1991) Nucleic Acids Res., 19, 4008.

18. Bentzen,P., Harris,A. and Wright,J.M. (1991) in Burke,T., Dolf,G., Jeffreys,A.J. and Wolff,R. (eds), DNA Fingerprinting: Approaches and Applications. Birkhauser Verlag, Besel, pp. 243-262.

19. Jeffreys,A.J., Royle,N.J., Wilson,V. and Wong,Z. (1988) Nature, 332, $278-281$.

20. Jeffreys,A.J., Macleod,A., Tamaki,K., Neil,D.L. and Monkton,D.G. (1991) Nature, 354, 204-209.

21. Nelson,D.L., Ledbetter,S.A., Corbo,L., Victoria,M.F., Ramirez-Solis,R., Webster,T.D., Ledbetter,D.H. and Caskey,C.T. (1989) Proc. Natl. Acad. Sci. U.S.A., 86, 6686-6690. 